\section{BRS Novo Horizonte - a new cassava variety for industrial use}

\author{
Eder Jorge de Oliveira ${ }^{1 *}$, Wânia Maria Gonçalves Fukuda ${ }^{1}$, \\ Saulo Alves Santos de Oliveira ${ }^{1}$, Rudiney Ringenberg ${ }^{1}$, Marcos \\ Roberto Silva ${ }^{2}$, Alan da Silva Souza ${ }^{3}$, André Luís Lordelo Silva ${ }^{3}$, \\ Manoel dos Santos Oliveira Filho ${ }^{3}$, Marcelo Lopes Faria ${ }^{3}$ and \\ Rogério de Jesus Santos Silva ${ }^{3}$
}

\begin{abstract}
The new cassava variety 'BRS Novo Horizonte' was developed and released in Bahia, Brazil for industrial use, particularly for starch production. The fresh and dry root yields were $39 \%$ and $44 \%$ higher, respectively, than those of local varieties. The root quality traits allowed the extraction of high-quality starch. The variety is also adapted for mechanized cropping systems.
\end{abstract}

Keywords: Manihot esculenta crantz, starch production, industrial variety.

\section{INTRODUCTION}

Cassava (Manihot esculenta Crantz) is a very important economic crop in Brazil because it produces starch, which is widely used in several industrial applications. According to the official data on cassava production in Brazil, annual root production is approximately 18 million tons, produced on a total of 1.3 million hectares (IBGE 2019).

Cassava root yield in Brazil is very low $\left(14.4 \mathrm{t} \mathrm{ha}^{-1}\right)$ in comparison with the potential of this crop, which can reach $42 \mathrm{t} \mathrm{ha}^{-1}$ when improved and adapted cultivars are used (Vieira et al. 2020). The situation is even worse in the state of Bahia, where root yields are approximately $8.5 \mathrm{t} \mathrm{ha}^{-1}$ (IBGE 2019). Environmental factors such as the occurrence of prolonged droughts, the use of unsuitable varieties, and the non-adoption of appropriate management techniques may explain this low yield potential. On the other hand, modernization of the cassava production system has recently occurred in northeastern Brazil, specifically in the state of Bahia, with starch companies focusing on the large-scale production of cassava for starch extraction. Therefore, from a varietal point of view, the main changes needed in this new large-scale production process are new varieties with high root and starch production potentials that are also suitable for mechanized cropping systems.

In the last 10 years, Embrapa Mandioca e Fruticultura (CNPMF) has expanded the development of varieties that meet the demands of the cassava starch industrial market. Based on the agronomic evaluation of several varieties in different years and regions of cultivation in the state of Bahia, it was concluded that the BRS Novo Horizonte variety showed high root yield and dry matter content in the roots, in addition to being suitable for mechanized cropping
Crop Breeding and Applied Biotechnology 20(2): e28882028, 2020 Brazilian Society of Plant Breeding. Printed in Brazil http://dx.doi.org/10.1590/198470332020v20n2c24
*Corresponding author:
E-mail: eder.oliveira@embrapa.br
(D) ORCID: 0000-0001-8992-7459

Received: 25 August 2019 Accepted: 11 March 2020 Published: 15 April 2020

\footnotetext{
${ }^{1}$ Embrapa Mandioca e Fruticultura, 44.380000, Cruz das Almas, BA, Brazil 2 Universidade Federal do Recôncavo da Bahia, 44.380-000, Cruz das Almas, BA, Brazil ${ }^{3}$ Bahiamido S.A, 45490-000, Laje, BA, Brazil
} 
systems. As a consequence, the BRS Novo Horizonte variety can be thought of an interesting alternative that may be used to expand the cassava cultivation area in the state of Bahia. This study presents the agronomic data and the main traits of the BRS Novo Horizonte industrial cassava variety in comparison with local varieties in the area of recommendation.

\section{CROSSING AND SELECTION}

The BRS Novo Horizonte variety was obtained via phenotypic selection in a segregating population from a crossing between accessions BGM0116 (female parental) and BGM1727 (male parental) (Figure 1). Artificial crosses were carried out in 1998 at Embrapa Mandioca e Fruticultura, in which female and male flowers were covered with a voile bag before opening. At the appropriate stage of their physiological maturation, pollinations were performed between 10:00 and 16:00. The pollinated flowers were covered again and the identities of the parents, date of crossing, and number of flowers crossed were recorded for each individual. The seeds obtained were stored at 4 으 for a period of two months before germination in substrate trays (coconut fiber, vermiculite, and plantimax, at a proportion of 1:1:1 v/v).

In 1999, phenotypic selection was performed in the seedling evaluation trial (SET), in which plants of each $F_{1}$ cassava progeny were evaluated in single-plant trials. The SET was planted without any experimental design, aiming only for the growth and generation of $\mathrm{F}_{1}$ plants for subsequent clonal propagation. Twelve months after planting, the plants were harvested and were evaluated for high-heritability traits such as plant shape and architecture, pulp, skin, and cortex color, and root shape.

The optimal clones identified in the SET were planted in 2000 for phenotypic selection of the best clones in the clonal evaluation trial (CET), taking into account germination rate and plant vigor. At this stage, the clones in the first phase of clonal propagation were planted in single rows with 5-6 plants per plot. In the preliminary yield trial (PYT), carried out in 2001, the best $F_{1}$ clones were selected based on the fresh and dry root yields. The PYT for the second phase of clonal propagation was planted in double rows composed of eight plants each (16 plants total per plot). All previous trials (SET, CET, and PYT) were performed in Cruz das Almas (BA).

Between 2011 and 2014, three advanced yield trials (AYT) were performed in the cities of Cruz das Almas (BA) and Presidente Tancredo Neves (BA), in order to select the best clones for further evaluation in different production regions, focusing on the highest fresh and dry root yields compared to local varieties used as checks (Cigana Preta, Corrente, and IAC90). The clones were evaluated in the third phase of clonal propagation, distributed in four rows composed of eight plants each (32 plants total per plot).

From 2015 to 2016, 14 uniform yield trials (UYT) were carried out in Cruz das Almas, Laje, and Santo Amaro (Bahia municipalities) for two consecutive years. Phenotypic selections were made based on fresh and dry root yields, dry matter content, plant height, and the pulp and cortex color of the roots. For the UYTs, the plots consisted of six rows composed of 10 plants each (60 plants total per plot).

In all trials, the spacing recommended for the region ( $0.90 \mathrm{~m}$ between rows and 0.80 between plants), as well as the technical recommendations for fertilization and crop management (Souza et al. 2006), were adopted. The main agronomic traits analyzed were plant height $(\mathrm{m})$; fresh root yield $\left(\mathrm{t} \mathrm{ha}{ }^{-1}\right)$; dry matter content of the roots (in \%, according

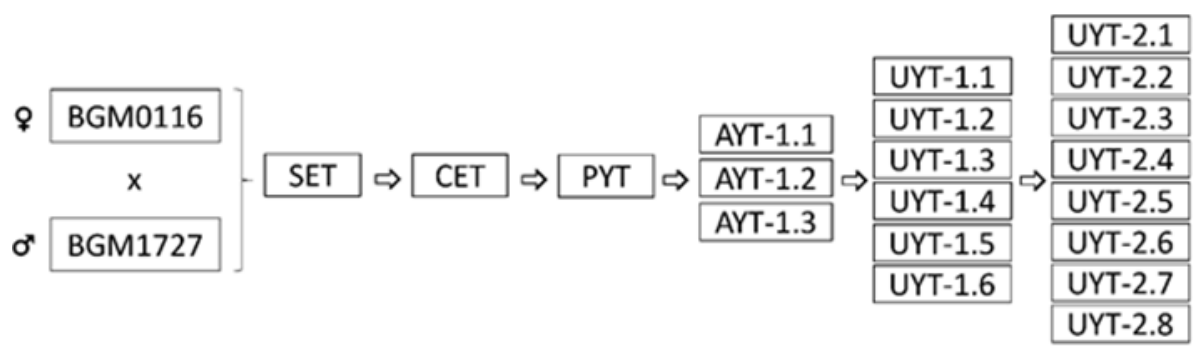

Figure 1. Breeding scheme for the development of the BRS Novo Horizonte cassava variety. After the original crossing of BGM0116 $\times$ BGM1727, the phenotypic selection followed the breeding pipeline for cassava. SET: seedling evaluation trial, CET: clonal evaluation trial, PYT: preliminary yield trial, AYT: advanced yield trial (three locations in one year), UYT: uniform yield trial (six locations in the first year and eight locations in the second year). 
to Andrade et al. 2019); and dry root yield ( $\mathrm{t} \mathrm{ha}^{-1}$, calculated as the dry matter content multiplied by the fresh root yield). The harvest index (in \%, obtained by the ratio between fresh root yield and total biomass-shoot and root weight) was analyzed as a secondary trait in the selection process.

\section{ADAPTATION AND YIELD DATA}

The soil characteristics of the three locations in which the cassava variety was evaluated are presented in Table 1. Yield data and other agronomic traits for the 2011-2016 harvests of the BRS Novo Horizonte variety in the 17 AYT and UYT trials in these locations (the Bahian cities of Cruz das Almas, Laje, and Santo Amaro) are presented in Figure 2.

The average fresh root yield of the BRS Novo Horizonte variety was $27.50 \mathrm{t} \mathrm{ha}^{-1}$ (ranging from 14.18 to $44.27 \mathrm{t} \mathrm{ha}^{-1}$ ), which is $39 \%$ higher than that of the local varieties (Figure $2 A$ ). Similar to fresh root yield, the dry root yield of BRS Novo Horizonte was $8.95 \mathrm{t} \mathrm{ha}^{-1}$ (ranging from 4.68 to $15.41 \mathrm{t} \mathrm{ha}^{-1}$ ), 44\% higher than the local varieties (Figure 2B).

The white root pulp of BRS Novo Horizonte, as well as its cream-colored root skin and cortex, are advantageous for starch extraction because the presence of dark points are minimized, and therefore the quality of the starch for the food industry is high (Figure 3). In addition, the BRS Novo Horizonte variety has a high dry matter content in the roots, approximately $36.98 \%$ (ranging from 32.33 to $39.44 \%$ ), which increases the industrial efficiency of starch extraction. Compared to the local varieties, the gains in dry matter content were $6.5 \%$ (Figure $2 \mathrm{C}$ ).

Table 1. Locations and soil characteristics for the trials used to release the BRS Novo Horizonte variety

\begin{tabular}{|c|c|c|c|}
\hline Municipality & Altitude $(\mathrm{m})$ & Coordinates & Soil classification \\
\hline Cruz das Almas & 225 & $12 \div 40^{\prime} \mathrm{S}, 39 \div 06^{\prime} \mathrm{W}$ & Yellow Latosol and Argisol \\
\hline Laje & 190 & $12 \circ 36^{\prime} \mathrm{S}, 38 \div 44^{\prime} \mathrm{W}$ & Red Yellow Podzolic - Medium Texture \\
\hline Santo Amaro & 88 & $13 \circ 10^{\prime} \mathrm{S}, 39 \circ 25^{\prime} \mathrm{W}$ & Cambisols and vertisols \\
\hline
\end{tabular}
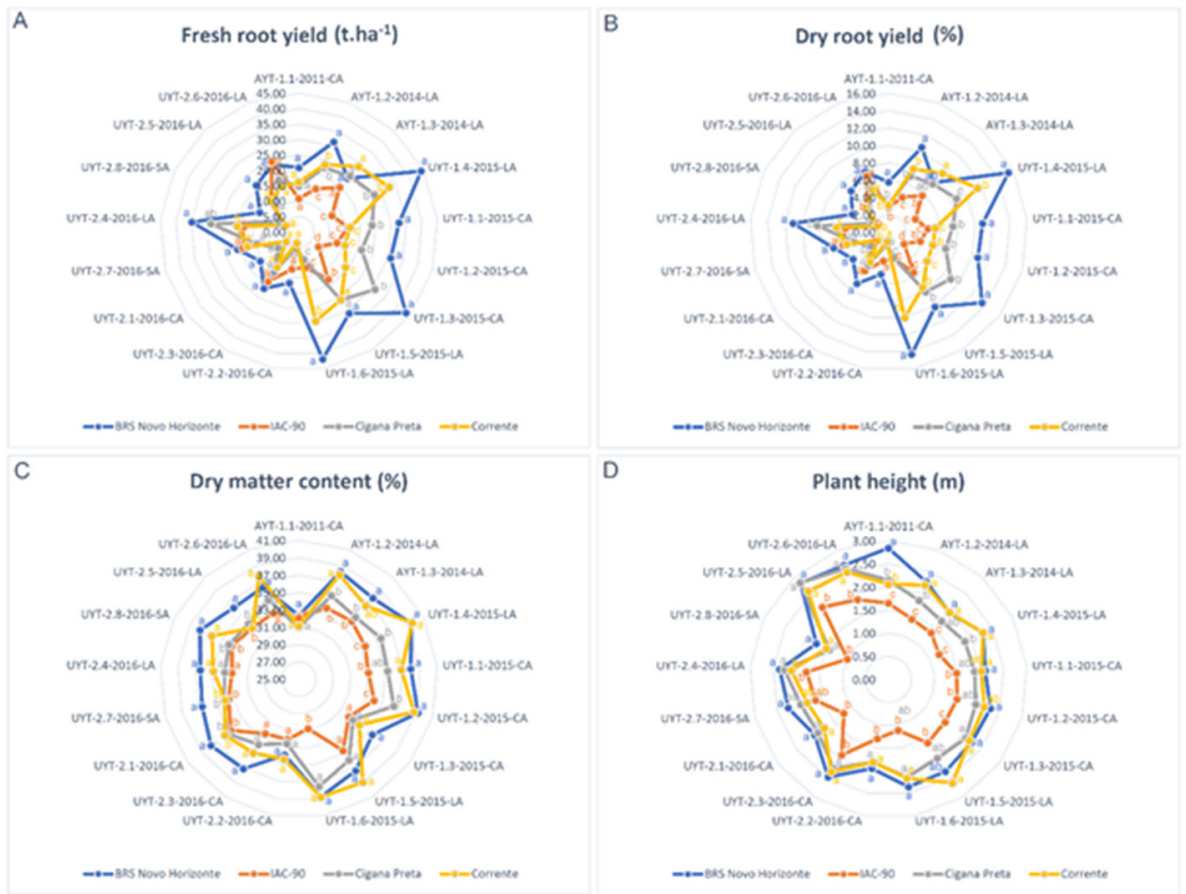

Figure 2. Performance of the BRS Novo Horizonte cassava variety and checks (Cigana Preta, Corrente, and IAC90 local varieties) in the cities of Cruz das Almas (CA), Laje (LA), and Santo Amaro (SA), State of Bahia, in the 2011 to 2016 growing seasons. AYT: advanced yield trial (three locations in one year), UYT: uniform yield trial (six locations in the first year and eight locations in the second year). Different letters in the same environment indicate significant differences (Tukey's test, $p<0.05$ ). 


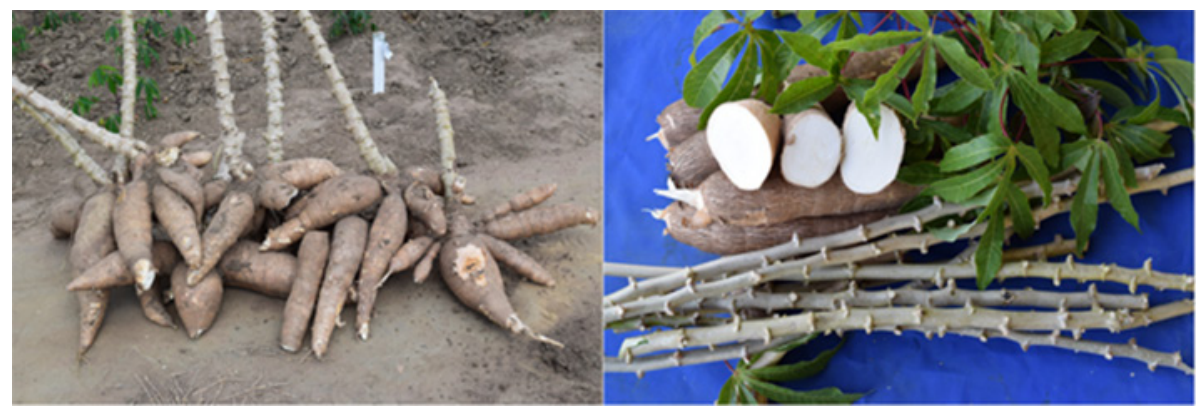

Figure 3. General appearance of BRS Novo Horizonte roots harvested at 12 months after planting.

The average harvest index of the BRS Novo Horizonte variety was $47.85 \%$ (ranging from 29.85 to $61.84 \%$ ), which represents a decrease of $7 \%$ compared to other local varieties (data not shown). This means that BRS Novo Horizonte has high shoot biomass production ability without large reductions in root yield, based on the relatively high root yield in comparison with the local varieties.

Regarding plant architecture, in most of the trials, BRS Novo Horizonte was an erect plant, although some plants may have branches around $1.60 \mathrm{~m}$ above the ground; this growth pattern allows its use in mechanized cropping systems (Figure 4). In addition, due to the high shoot biomass production and large number of leaves, greater soil cover and a consequent reduction in the number of interventions needed for weed control were observed. The average height of BRS Novo Horizonte plants was $2.29 \mathrm{~m}$ (ranging from 1.74 to $2.84 \mathrm{~m}$ ), which is $17 \%$ higher than the local varieties (Figure 2D).

\section{OTHER TRAITS}

The resistance of BRS Novo Horizonte to shoot (anthracnose, brown leaf spot, white leaf spot, and blight leaf burning) and root diseases (cassava root rot) was observed

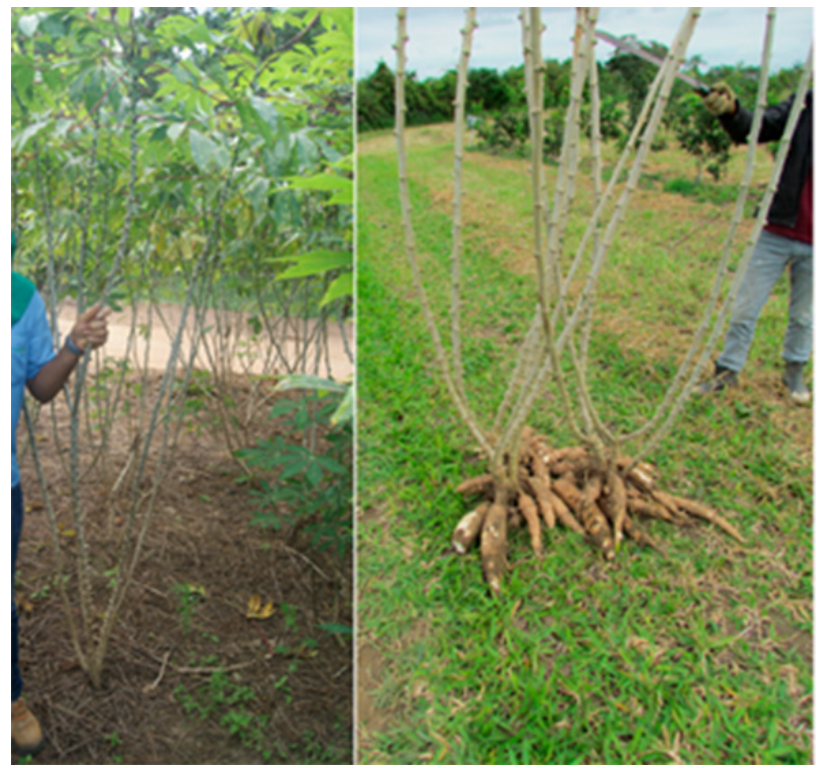

Figure 4. Overview of BRS Novo Horizonte shoots at nine months after planting. In general, the stems are erect, but there may be plants with branches approximately $1.60 \mathrm{~m}$ above ground; this architecture allows the use of this variety in mechanized planting systems to be slightly stronger than that of local varieties, including greater leaf retention at the end of the maturation cycle. Evaluations for cassava bacterial blight resistance were not performed in the field, as this disease occurs only sporadically in the regions recommended for BRS Novo Horizonte.

The main morphological descriptors that distinguish the BRS Novo Horizonte variety from other varieties grown in the recommended regions are presented in Table 2.

\section{TECHNICAL RECOMMENDATION AND CUTTING-SEED PRODUCTION}

The production system used in the agronomic evaluation of the BRS Novo Horizonte variety followed the technical recommendations for cassava crop management in the State of Bahia, which included conventional tillage (plowing, harrowing, furrowing) and planting of cutting pieces 16 to $18 \mathrm{~cm}$ in length, with a spacing of $0.90 \mathrm{~m}$ between rows and $0.80 \mathrm{~m}$ between plants. Weeds were controlled using pre-emergent herbicides as well as by manual weeding performed twice at approximately 60 and 90 days after planting. The fertilization followed the recommendations found in Souza et al. (2006). Harvesting occurred 11-12 months after planting. 
BRS Novo Horizonte - a new cassava variety for industrial use

Table 2. Main morphological traits of the BRS Novo Horizonte variety

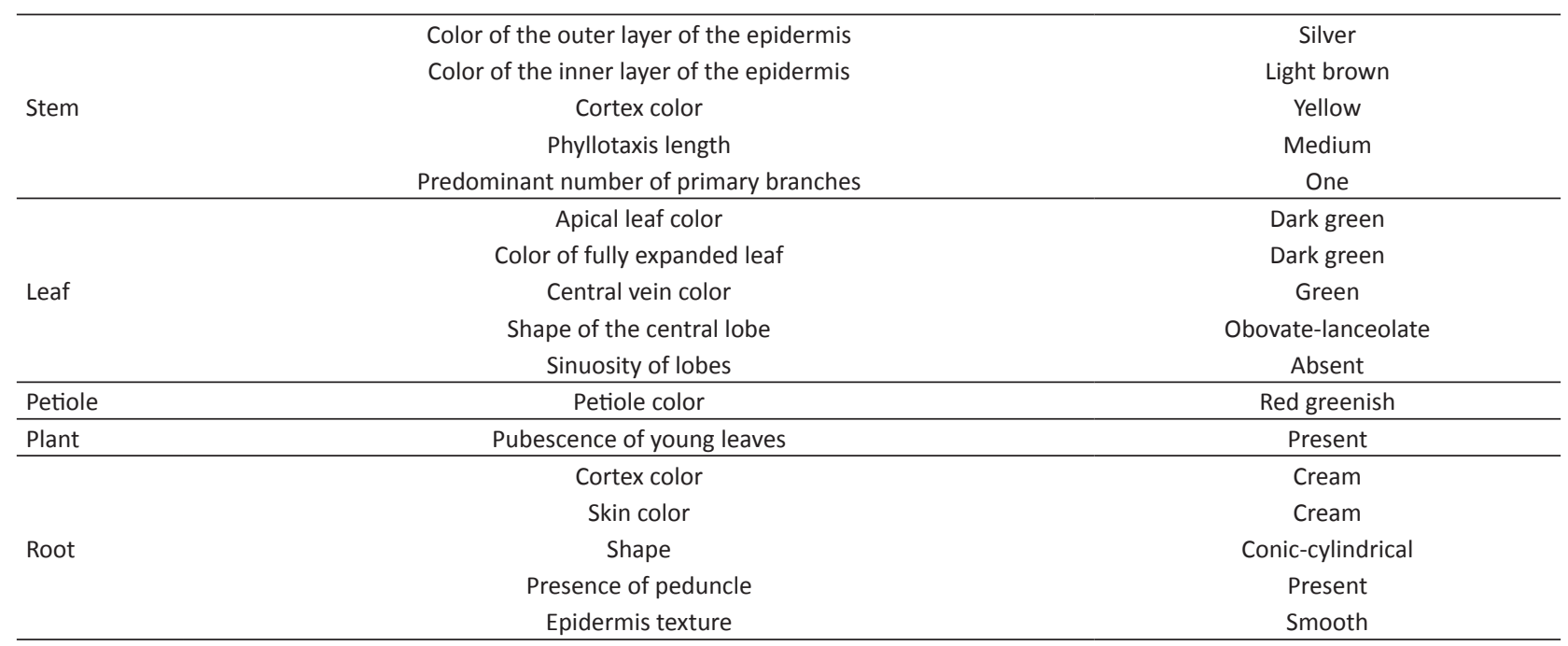

The BRS Novo Horizonte cultivar were registered by the Ministry of Agriculture, Livestock and Supply, in August 2017 (N. 37275). The Empresa Brasileira de Pesquisa Agropecuária (Embrapa) is responsible for the basic cutting-seed production.

\section{ACKNOWLEDGEMENTS}

The authors thank CNPq (Conselho Nacional de Desenvolvimento Científico e Tecnológico), FAPESB (Fundação de Amparo à Pesquisa do Estado da Bahia), CAPES (Coordenação de Aperfeiçoamento de Pessoal de Nível Superior), and Bahiamido S.A. for their financial assistance and scholarship support.

\section{REFERENCES}

Andrade LRB, Sousa MB, Oliveira EJ, Resende MDV and Azevedo CF (2019) Cassava yield traits predicted by genomic selection methods. Plos One 14: e0224920.

IBGE - Produção Agrícola Municipal (2019) Available at: <https://www. ibge.gov.br/estatisticas/economicas/agricultura-e-pecuaria.html>. Accessed on August 10, 2019.
Souza LS, Farias ARN, Mattos PLP and Fukuda WMG (2006) Aspectos socioeconômicos e agronômicos da mandioca. Embrapa Mandioca e Fruticultura, Cruz das Almas, 817p.

Vieira EA, Freitas Fialho J, Oliveira CM, Rinaldi MM and Fernandes FD (2020) New cassava cultivars for starch and flour production in the Cerrado of Central Brazil. Crop Breeding and Applied Biotechnology 20(1): e27362023. 